\title{
Islet Cell Tumor in von Hippel-Lindau Disease
}

\author{
Nobumasa Mizuno, Satoru Naruse, Motoji Kitagawa, Hiroshi Ishiguro, Yasuyuki Nakae, Hideaki Ieda, \\ Naohiko Izzuka, Osamu Ito, Yasunaga Seki, Shigeru B.H. Ko, Toshiyuki Yoshikawa, Tetsuo HayaKawa, \\ Tsuyoshi SAnO*, Junichi KamiYa*, Yuji Nimura* and Tetsuro NAGASAKA**
}

We describe a 42-year-old man with von Hippel-Lindau disease and islet cell tumor of the pancreas. He had retinal and cerebellar hemangioblastomas. His sister had pheochromocytoma. A pancreatic tumor was detected by ultrasonography at his periodical medical checkup. Contrast enhanced computed tomography and abdominal angiography revealed a hypervascular tumor in the pancreatic head. Histological examination of the resected tumor revealed characteristics of islet cell tumor of the pancreas, which was positive for chromogranin-A, S-100 protein, and pancreatic polypeptide, but was negative for insulin, gastrin, glucagon, somatostatin, vasoactive intestinal peptide, serotonin, and adrenocorticotropic hormone.

(Internal Medicine 37: 295-299, 1998)

Key words: pancreatic polypeptide producing tumor, hemangioblastoma

\section{Introduction}

Von Hippel-Lindau (VHL) disease is an autosomal dominant disorder that causes a variety of neoplastic diseases such as hemangioblastomas of the central nervous system (CNS), retinal hemangioblastomas, renal cell carcinomas, pheochromocytomas, renal and pancreatic cysts, and epididymal cystadenomas (1, 2). In 1964, Melmon and Rosen (3) reported a large number of families with VHL disease and proposed a diagnostic criteria: two or more hemangioblastomas, or a single hemangioblastoma in association with a visceral manifestation. When there is a family history of retinal or CNS hemangioblastoma, only one hemangioblastoma or visceral manifestation is required. In VHL disease, pancreatic cysts are common, but islet cell tumor of the pancreas is very rare $(1,2,4)$. We describe a patient with VHL disease who had pancreatic polypeptide (PP) producing tumor of the pancreas.

\section{Case Report}

A 42-year-old man was admitted to our hospital because of a pancreatic tumor detected by ultrasonography at his periodical medical checkup. Retinal hemangioblastoma was noted at the age of 13 and his left eye was removed at the age of 15 . He had no symptom except for progressive impairment of vision. His elder sister died of pheochromocytoma at the age of 27.
On physical examination, his blood pressure and pulse were $110 / 64 \mathrm{mmHg}$ and $60 / \mathrm{min}$. His right visual acuity was 0.1 . The abdomen was soft and flat, and the tumor was not palpable. Dermatological and neurological examinations revealed no abnormalities.

Laboratory examinations were normal, including complete blood counts, blood chemistry, endocrine tests and tumor markers. Plasma levels of insulin, gastrin, glucagon, pituitary hormones, thyroid hormones, and parathyroid hormone were normal. Urinary levels of catecholamines and their metabolites were normal. Exocrine and endocrine pancreatic function test were normal (Table 1). Ultrasonography (US) showed a round and hypoechoic mass $(4.0 \times 4.0 \mathrm{~cm})$ in the pancreatic head. Endoscopic ultrasonography showed a well-defined hyperechoic mass with hypoechoic spots. Computed tomography (CT) showed a hypodense mass, and dynamic contrast enhanced study showed a hypervascular mass with a central necrosis (Fig. 1). Imaging studies of kidneys and adrenal glands revealed only a renal cyst on the right. Axial magnetic resonance imaging (MRI) showed a mass which was hypointense on T1-weighted images and hyperintense on T2-weighted images. Endoscopic retrograde cholangiopancreatography showed displacement of the main pancreatic duct without stenosis and irregularities of branches. Celiac and superior mesenteric arteriography revealed hypervascular masses in the pancreatic head (Fig. 2). Fluorescein angiography demonstrated a retinal hemangio-

From the Departments of Internal Medicine II and *Surgery I, Nagoya University School of Medicine and **the Division of Pathology Clinical Laboratory, Nagoya University Hospital, Nagoya

Received for publication February 21, 1997; Accepted for publication October 7, 1997

Reprint requests should be addressed to Dr. Satoru Naruse, the Department of Internal Medicine II, Nagoya University School of Medicine, 65 Tsuruma-cho, Showa-ku, Nagoya 466-8560 
Table 1. Laboratory Findings on Admission

\begin{tabular}{lrlr}
\hline Aspartate amino transferase & $13 \mathrm{IU} / l$ & Adrenocorticotropic hormone & $46.1 \mathrm{ng} / \mathrm{ml}$ \\
Alanine amino transferase & $15 \mathrm{IU} / l$ & Growth hormone & $0.6 \mathrm{ng} / \mathrm{ml}$ \\
Lactate dehydrogenase & $128 \mathrm{IU} / l$ & Prolactin & $21.7 \mathrm{ng} / \mathrm{ml}$ \\
Alkaline phosphatase & $210 \mathrm{IU} / l$ & Thyroid-stimulating hormone & $1.54 \mathrm{mU} / \mathrm{ml}$ \\
Total bilirubin & $0.7 \mathrm{mg} / \mathrm{dl}$ & Free triiodothyronine & $2.84 \mathrm{ng} / \mathrm{ml}$ \\
Total amylase & $79 \mathrm{IU} / l$ & Free thyroxine & $1.25 \mathrm{ng} / \mathrm{dl}$ \\
Pancreatic amylase & $50 \mathrm{IU} / l$ & Intact parathyroid hormone & $22.6 \mathrm{ng} / \mathrm{ml}$ \\
Salivary amylase & $29 \mathrm{IU} / l$ & Insulin & $6 \mathrm{mU} / \mathrm{ml}$ \\
Lipase & $21 \mathrm{IU} / l$ & Gastrin & $47.2 \mathrm{pg} / \mathrm{dl}$ \\
Elastase-1 & $10.8 \mathrm{ng} / \mathrm{dl}$ & Glucagon & $95 \mathrm{pg} / \mathrm{dl}$ \\
Trypsin & $185 \mathrm{ng} / \mathrm{ml}$ & Urinary adrenaline & $1.8 \mathrm{mg} / \mathrm{day}$ \\
PSTI & $8.4 \mathrm{ng} / \mathrm{ml}$ & Urinary noradrenaline & $6.2 \mathrm{mg} / \mathrm{day}$ \\
PLA 2 & $298.9 \mathrm{ng} / \mathrm{dl}$ & Urinary dopamine & $52 \mathrm{mg} / \mathrm{day}$ \\
CEA & $1.7 \mathrm{ng} / \mathrm{ml}$ & Urinary VMA & $3.1 \mathrm{mg} / \mathrm{day}$ \\
CA19-9 & $<5 \mathrm{U} / \mathrm{ml}$ & Urinary HMA & $3.0 \mathrm{mg} / \mathrm{day}$ \\
NBT-PABA test & $74.7 \%$ & Urinary 5-HIAA & $2.9 \mathrm{mg} / \mathrm{day}$ \\
Fecal chymotrypsin & $23.6 \mathrm{U} / \mathrm{g}$ & $75 \mathrm{~g}$ OGTT & Glucose \\
Secretin test & & & $95 \mathrm{mg} / \mathrm{day}$ \\
MBC & $88.6 \mathrm{mEq} / \mathrm{l}$ & & 163 \\
Volume & $385 \mathrm{ml}$ & & 119 \\
Amylase output & $15.2 \times 10^{4} \mathrm{U}$ & & $60^{\prime}$
\end{tabular}

PSTI: pancreatic secretary trypsin inhibitor, PLA 2 : phospholipase $\mathrm{A}_{2}, \mathrm{CEA}$ : carcinoembryonic antigen, CA19-9: carbohydrate antigen 19-9, NBT-PABA: N-benzoyl-L-tyrosyl-p-aminobenzoic acid, MBC: maximal bicarbonate concentration, VMA: vanillylmandelic acid, HMA: homovanillic acid, 5-HIAA: 5-hydroxyindoleacetic acid, OGTT: oral glucose tolerance test.

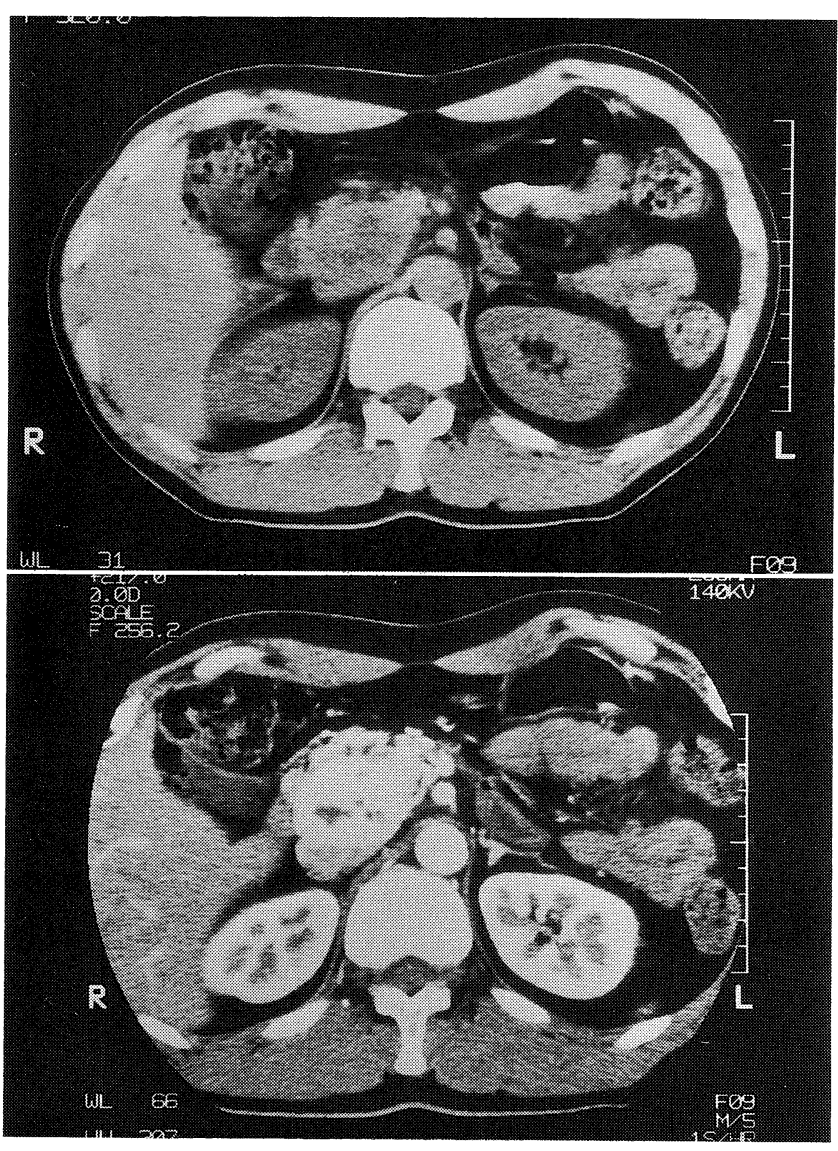

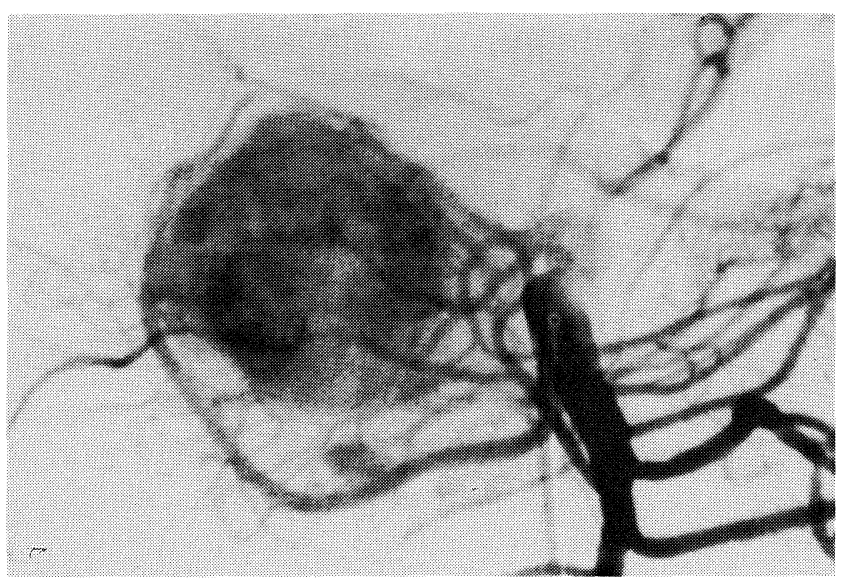

Figure 2. Superior mesenteric arteriography shows hypervascular masses.

Figure 1. Upper: Unenhanced CT shows a hypodense mass in the pancreatic head. Lower: Contrast enhanced CT shows a hyperdense mass with hypodense spots. 
blastoma on the right (Fig. 3). Gadolinium-enhanced T2weighted axial MRI showed a hemangioblastoma on the left cerebellum (Fig. 4). Pituitary gland was normal.

Based on these findings, we diagnosed him as a VHL disease and an islet cell tumor of the pancreas. The patient underwent pylorus-preserving pancreaticoduodenectomy. During the operation, there was no evidence of metastasis in the liver or lymph nodes.

Macroscopically, the resected tumor $(4.5 \times 4.0 \times 2.5 \mathrm{~cm})$ was elastic hard and well defined with a fibrous capsule. The cut

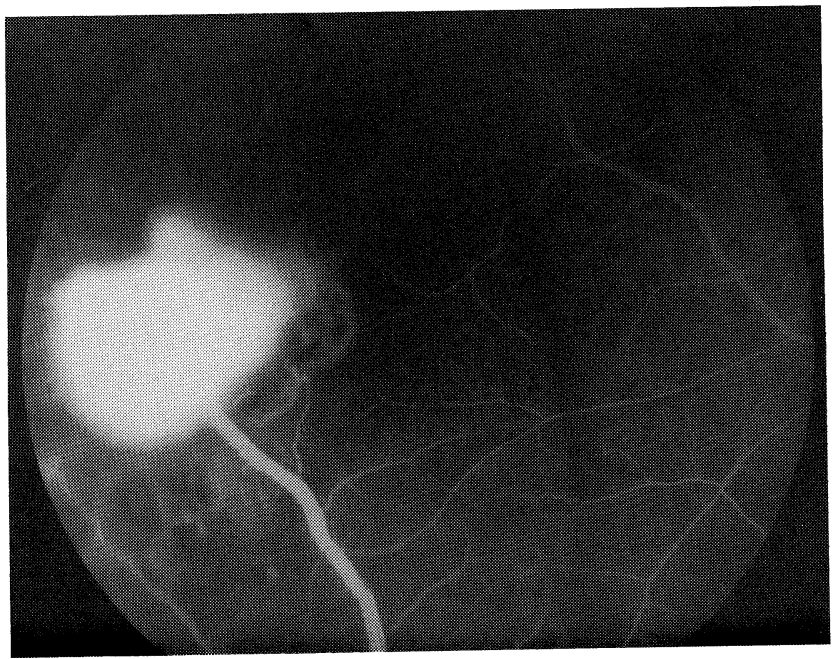

Figure 3. Fluorescein angiography shows a retinal hemangioblastoma on the right.

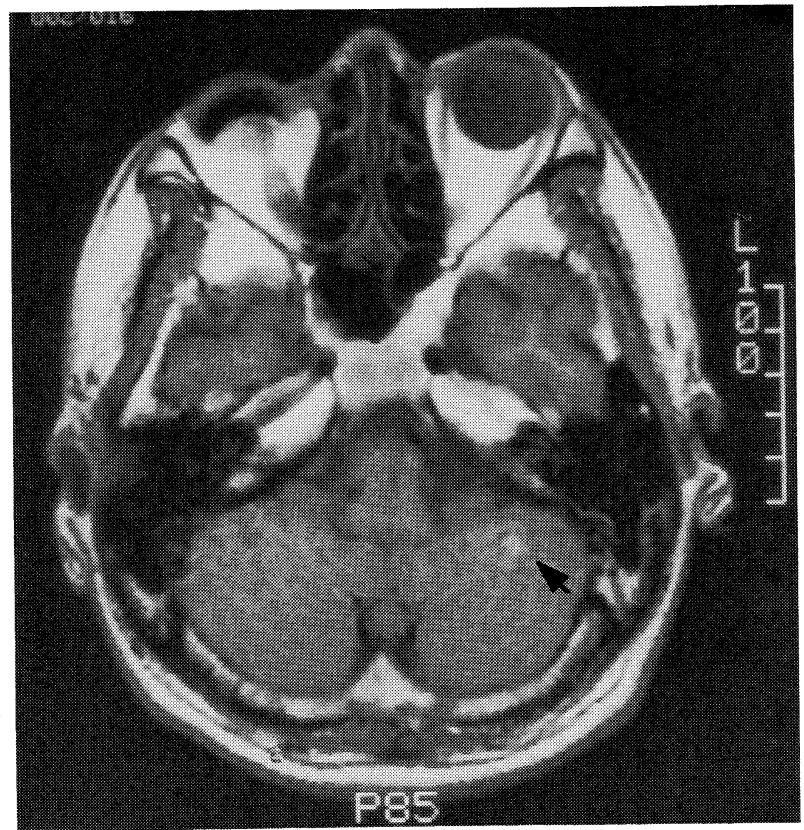

Figure 4. T2-weighted axial MRI shows a hemangioblastoma in the left cerebellum (arrow). surface of the tumor showed a solid mass with necrosis. Three other small tumors were detected in the resected pancreas. Microscopically, the tumor cells were arranged in a trabecular pattern, and had clear granular, eosinophilic cytoplasm, and round nuclei. Mitoses were rare. The small tumors were compatible with islet hyperplasia. Immunohistochemically, the tumor cells were positive for chromogranin-A, S-100 protein, and PP. No immunoreactivity was demonstrated for gastrin, insulin, glucagon, somatostatin, vasoactive intestinal peptide (VIP), serotonin and adrenocorticotropic hormone.

\section{Discussion}

VHL disease is categorized as neurocutaneous syndromes or phacomatoses together with neurofibromatosis (von Recklinghausen's disease), tuberous sclerosis (Bourneville's disease), encephalotrigeminal syndrome (Sturge-Weber disease),

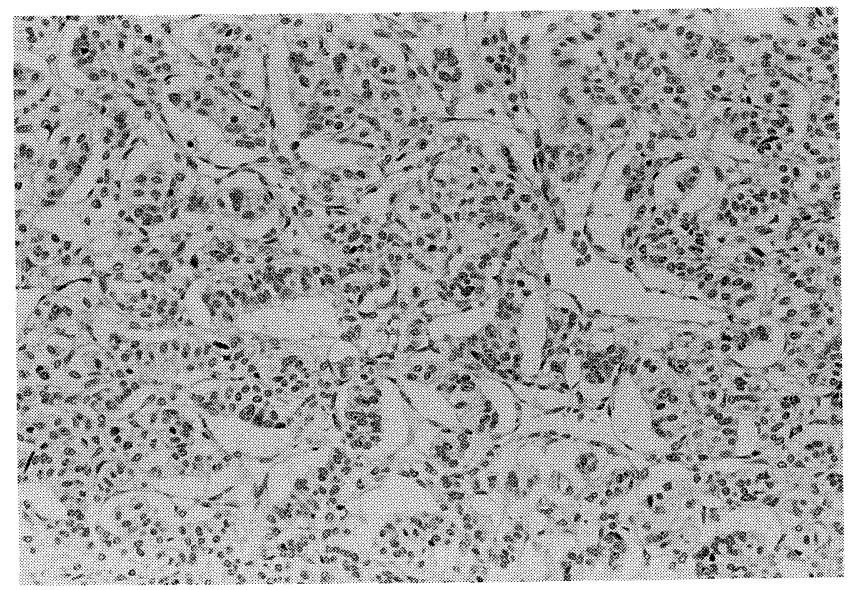

Figure 5. The tumor cells show a trabecular pattern. Most of tumor cells have clear granular and eosinophilic cytoplasm, and round nuclei $($ HE stain, $\times 50)$.

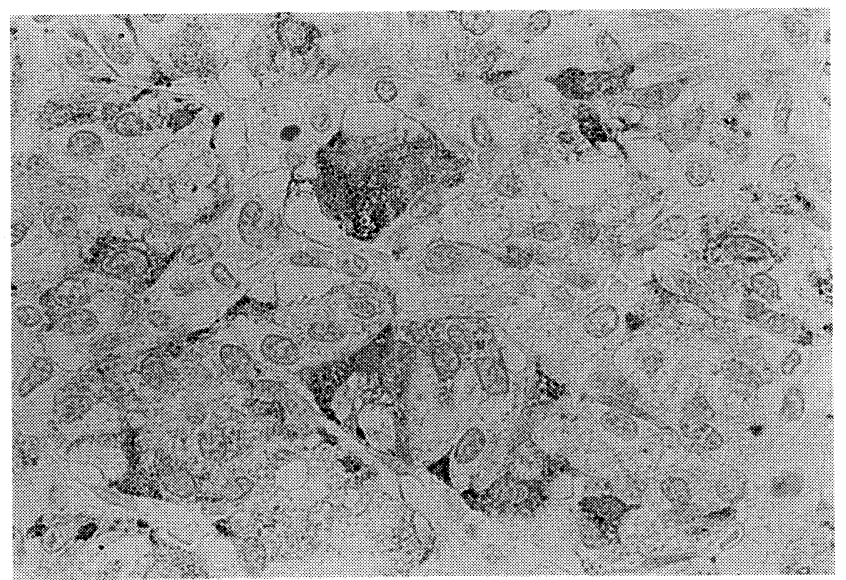

Figure 6. Immunohistochemical staining for pancreatic polypeptide $(\times 200)$. 
and ataxia telangectasis (Louis-Bar syndrome), but skin lesions are not common in VHL disease $(5,6)$. The gene of VHL disease was identified and mapped to the short arm of chromosome 3p25-26 (7). The present case had a retinal hemangioblastoma, a pancreatic tumor, and probably a cerebellar hemangioblastoma revealed by MRI. He had a definite VHL disease. His sister is also assumed to have had a VHL disease according to Melmon's criteria (3), because she had a family history of VHL disease and died of pheochromocytoma.

Retinal hemangioblastomas may be the earliest manifestation of VHL disease. The mean age at diagnosis is 21-28 years. Multiple or bilateral lesions occur in $20 \%-58 \%$ of patients, and $16 \%-36 \%$ of those with retinal lesions have diminished vision (1). In this case, retinal hemangioblastoma in the left eye was noted at the age of 13 , and impaired vision appeared gradually in the right eye.

Hemangioblastomas of CNS in VHL disease are usually benign, and associated morbidity is due to space-occupying effects. Renal cell carcinoma is a major cause of death (1). Renal cysts, hemangioblastomas and benign adenomas are usually asymptomatic in VHL disease. The present case had hemangioblastomas and renal cyst without neurological abnormalities and abdominal symptoms.

The common pancreatic diseases in VHL disease include pancreatic cyst, cystadenoma and cystoadenocarcinoma $(8,9)$. Pancreatic cysts were found in $72 \%$ of patients with VHL disease at autopsy (10). The prevalence of islet cell tumors of the pancreas in VHL disease was difficult to assess accurately, because most of the published reports were the case reports of a few patients or limited to kindred studies $(2,9-24)$. Binkovitz et al reported that 6 of 43 patients from 25 kindreds with VHL disease had islet cell tumor of the pancreas (4). Table 2 reviews 25 patients with an islet cell tumor of the pancreas in VHL disease. Most of the patients were asymptomatic. Four patients had abdominal pain, two had metastatic diseases and one had abdominal tumor. Immunohistochemical examination for gastrointestinal hormones was performed in 10 of 24 cases. Two tumors were positive for either PP or somatostatin, one for insulin, glucagon and PP, one for both calcitonin and VIP, both gastrin and VIP, or VIP alone. Most of the patients had no endocrinological symptoms. Only two patients complained of watery diarrhea due to oversecretion of VIP. In our case, tumor cells were positive for PP, but he was asymptomatic. The physiological role of PP is the inhibition of pancreatic secretion and biliary tract motility (25). No typical clinical presentation was, however, seen in the reported cases of PP producing tumors (26-29). The present case had no endocrinological abnormalities and no abdominal symptoms. Pancreatic tumor was detected at his periodical medical checkup incidentally. His exocrine and endocrine functions were also normal.

Pheochromocytomas are relatively common in familial cancer diseases. The incidence of the association of pheochromo-

Table 2. Islet Cell Tumors of the Pancreas in von Hippel-Lindau Disease

\begin{tabular}{|c|c|c|c|c|c|c|c|c|}
\hline $\begin{array}{l}\text { Case } \\
\text { No. }\end{array}$ & Age/Sex & $\begin{array}{l}\text { Family history } \\
\text { of VHLD }\end{array}$ & Initial symptoms or signs & Diagnosis & $\begin{array}{c}\text { Number of } \\
\text { lesions in pancreas }\end{array}$ & $\begin{array}{l}\text { Immunohistological } \\
\text { study }\end{array}$ & Associated tumors & References \\
\hline 1 & $27 / \mathrm{F}$ & Yes & Not described & ICC & 1 & Not performed & $\mathrm{HBC}$ & Cubilla et al (11) \\
\hline 2 & $20 / \mathrm{F}$ & Yes & None & Not described & Not described & None & $\mathrm{RH}, \mathrm{HBC}, \mathrm{RCC}$ & Horton et al (10) \\
\hline 3 & $33 / \mathrm{M}$ & Not described & Not described & ICA & Not described & Not performed & HBC, Pheo. & Andersson et al (12) \\
\hline 4 & $41 / \mathrm{M}$ & Not described & None & ICA & 1 & Insulin, glucagon, PP & RH, HBC, Pheo., syringomyelia & Probst et al (13) \\
\hline 5 & $23 / \mathrm{F}$ & Yes & None & ICC & 1 & Not performed & HBC, Pheo. & Hull et al (14) \\
\hline 6 & $17 / \mathrm{M}$ & Yes & None & ICC & 4 & Not performed & HBC, Pheo. & Hull et al (14) \\
\hline 7 & $56 / \mathrm{F}$ & Yes & Watery diarrhea, liver metastasis & ICC & 1 & Calcitonin, VIP & Pheo., RCC, pancreatic cyst & Cornish et al (15) \\
\hline 8 & 27/M & Yes & Watery diarrhea & $\mathrm{ICA}$ & 2 & VIP & RH, Pheo. & Mulshine et al (16) \\
\hline 9 & $26 / \mathrm{F}$ & Yes & None & Not described & 1 & Not performed & $\begin{array}{l}\mathrm{RH}, \mathrm{HBC}, \mathrm{RCC} \text {, renal cyst } \\
\text { Pancreatic cyst }\end{array}$ & Hardwig et al (17) \\
\hline 10 & $38 / \mathrm{F}$ & Yes & None & Not described & 1 & PP & $\begin{array}{l}\text { RH, HBC, pancreatic cyst } \\
\text { Renal cyst }\end{array}$ & Jennings et al (18) \\
\hline 11 & $41 / \mathrm{F}$ & Yes & Liver metastasis & ICC & 1 & Not performed & RH, renal cyst & Lamiell et al (19) \\
\hline 12 & $42 / \mathrm{F}$ & Not described & None & Not described & 1 & None & RH, HBC, RCC, renal cyst & Clelland et al (20) \\
\hline 13 & $43 / \mathrm{F}$ & Yes & None & ICA & Not described & Not performed & $\mathrm{RH}, \mathrm{RCC}$ & Binkovitz et al (4) \\
\hline 14 & $26 / \mathrm{F}$ & No & None & ICA & Not described & Not performed & $\begin{array}{l}\text { RH, HBC, RCC } \\
\text { Pancreatic cyst }\end{array}$ & Binkovitz et al (4) \\
\hline 15 & $28 / \mathrm{F}$ & Yes & None & ICA & 1 & Not performed & $\begin{array}{l}\text { HBC, Pheo., RCC } \\
\text { Pancreatic cyst }\end{array}$ & Binkovitz et al (4) \\
\hline 16 & $29 / \mathrm{F}$ & Yes & None & ICC & 1 & Not performed & Pheo., RCC, pituitary adenoma & Binkovitz et al (4) \\
\hline 17 & $36 / \mathrm{M}$ & Yes & Abdominal pain & ICC & 5 & Not performed & Liver cyst & Binkovitz et al (4) \\
\hline 18 & $57 / \mathrm{M}$ & Yes & Palpable mass & ICC & Not described & Not performed & $\mathrm{RH}, \mathrm{HBC}$ & Binkovitz et al (4) \\
\hline 19 & $28 / \mathrm{F}$ & Yes & Abdominal pain & ICC & 2 & Not performed & RH & Ikami et al (21) \\
\hline 20 & $50 / \mathrm{F}$ & Not described & Abdominal pain, BW loss & ICC & 2 & Not performed & $\mathrm{RH}, \mathrm{RCC}$, renal cyst & Neumann et al (9) \\
\hline 21 & $59 / \mathrm{M}$ & Yes & Not described & Not described & Not described & Gastrin, VIP & $\begin{array}{l}\text { HBC, Pheo., RCC, liver cyst } \\
\text { Pancreatic cyst }\end{array}$ & Karsdorp et al (2) \\
\hline 22 & Not described & Yes & Not described & Not described & Not described & Not performed & $\mathrm{RCC}$ & Walther et al (22) \\
\hline 23 & $21 / \mathrm{F}$ & Yes & Abdominal pain & ICA & 1 & Somatostatin & None & Mount et al (23) \\
\hline 24 & $39 / \mathrm{M}$ & Not described & None & ICA & 1 & Somatostatin & $\mathrm{HBC}, \mathrm{RCC}$ & Maki et al (24) \\
\hline 25 & $42 / \mathrm{M}$ & Yes & None & ICA & 4 & PP & $\mathrm{RH}, \mathrm{HBC}$, renal cyst & Our case \\
\hline
\end{tabular}

VHLD: von Hippel-Lindau disease, ICA: islet cell adenoma, ICC: islet cell carcinoma, PP: pancreatic polypeptide, VIP: vasoactive intestinal peptide, RH: retinal hemangioblastoma, HBC: hemangioblastoma of the central nervous system, Pheo.: pheochromocytoma, RCC: renal cell carcinoma. 


\section{Islet Cell Tumor in VHL Disease}

cytomas with the multiple endocrine neoplasia type 2 , neurofibromatosis type 1 , and VHL disease are reported to be $50 \%, 1 \%$, and $15 \%$, respectively (2). The frequency of VHL disease in unselected patients with pheochromocytoma is $19 \%$ (30). His sister had pheochromocytoma, but he had no clinical evidence of pheochromocytoma. His endocrinological examinations, such as blood levels of pituitary, thyroid, parathyroid and adrenal hormones and urinary levels of catecholamines and their metabolites, showed no abnormalities. Imaging studies showed no tumors in endocrine glands.

Table 2 summarizes the case reports of islet cell tumors associated with VHL disease. This shows that 10 of 19 patients $(53 \%)$ had a malignant tumor. Therefore, patients with a hemangioblastoma should have a careful review of the family history, brain CT or MRI, and abdominal CT or ultrasonography. Periodical medical checkup using ultrasonography would be very useful to detect a tumor in the liver, gall bladder, pancreas, kidney and adrenal gland.

Acknowledgements: This work is supported in part by a research grant for intractable pancreatic disease from the Ministry of Health and Welfare of Japan.

\section{References}

1) Choyke PL, Glenn GM, Walther MM, Patronas NJ, Linehan WM, Zbar B. von Hippel-Lindau disease: genetic, clinical, and imaging features. Radiology 194: 629, 1995.

2) Karsdorp N, Elderson A, Wittebol-Post D, et al. Von Hippel-Lindau disease: new strategies in early detection and treatment. Am J Med 97: 158, 1994.

3) Melmon KL, Rosen SW. Lindau's disease: review of the literature and study of a large kindred. Am J Med 36: 595, 1964.

4) Binkovitz LA, Johnson CD, Stephens DH. Islet cell tumors in von HippelLindau disease: increased prevalence and relationship to the multiple endocrine neoplasias. AJR 155: 501, 1990.

5) Thomas PK. Inherited disorders. in: Oxford Textbook of Medicine (third edition), Weatherall DJ, Ledingham JGG, Warrell DA, Eds. Oxford University Press, Oxford, 1996, p. 3984.

6) Caviness VS Jr. Neurocutaneous syndromes and other developmental disorders of the central nervous system. in: Harrison's Principles of Internal Medicine (13th edition), Isselbacher KJ, Braunwald $\mathrm{E}$, Wilson JD, Martin JB, Fauci AS, Kasper DL, Eds. McGraw-Hill, Inc., New York, 1994, p. 2339.

7) Latif F, Tory K, Gnarra J, et al. Identification of the von Hippel-Lindau disease tumor suppressor gene. Science 260: 1317, 1993.

8) Hough DM, Stephens DH, Johnson CD, Binkovitz LA. Pancreatic lesions in von Hippel-Lindau disease: prevalence, clinical significance, and CT findings. AJR 162: 1091, 1994.

9) Neumann HPH, Dinkel E, Brambs H, et al. Pancreatic lesions in the von Hippel-Lindau syndrome. Gastroenterology 101: 465, 1991.

10) Horton WA, Wong V, Eldridge R. Von Hippel-Lindau disease: clinical and pathological manifestations in nine families with 50 affected mem- bers. Arch Intern Med 136: 769, 1976.

11) Cubilla AL, Hajdu SI. Islet cell carcinoma of the pancreas. Arch Pathol 99: 204, 1975.

12) Andersson $\AA$, Bergdahl L. Insulomas and multiple endocrine neoplasia. Acta Chir Scand 142: 297, 1976.

13) Probst A, Lotz M, Heitz P. Von Hippel-Lindau's disease, syringomyelia and multiple endocrine tumors: a complex neuroendocrinopathy. Virchows Arch A Path Anat Histol 378: 265, 1978.

14) Hull MT, Warfel KA, Muller J, Higgins JT. Familial islet cell tumors in von Hippel-Lindau's disease. Cancer 44: 1523, 1979.

15) Cornish D, Pont A, Minor D, Coombs JL, Bennington J. Metastatic islet cell tumor in von Hippel-Lindau disease. Am J Med 77: 147, 1984.

16) Mulshine JL, Tubbs R, Sheeler LR, Gifford RW. Case report: clinical significance of the association of the von Hippel-Lindau disease with pheochromocytoma and pancreatic apudoma. Am J Med Sci 288: 212, 1984.

17) Hardwig P, Robertson DM. von Hippel-Lindau disease: a familial, often lethal, multi-system phakomatosis. Ophthalmology 91: 263, 1984.

18) Jennings AM, Smith C, Cole DR, et al. Von Hippel-Lindau disease in a large British family: clinicopathological features and recommendations for screening and follow-up. Q J Med 66: 233, 1988.

19) Lamiell JM, Salazar FG, Hsia YE. Von Hippel-Lindau disease: affecting 43 members of a single kindred. Medicine (Baltimore) 68: 1, 1989.

20) Clelland CA, Treip CS. Histological differentiation of metastatic renal carcinoma in the cerebellum from cerebellar haemangioblastoma in von Hippel-Lindau's disease. J Neurol Neurosurg Psychiatry 52: 162, 1989.

21) Ikami I, Munakata M, Tsuchida H, Matsumoto K, Yodono H, Takekawa S. Nonfunctioning islet cell carcinoma of the von Hippel-Lindau diseases: report of a case. Gazo Shindan 11: 1460, 1991 (in Japanese).

22) Walther MM, Choyke PL, Weiss G, et al. Parenchymal sparing surgery in patients with hereditary renal cell carcinoma. J Urol 153: 913, 1995.

23) Mount SL, Weaver DL, Taatjes DJ, McKinnon WC, Hebert JC. Von Hippel-Lindau disease presenting as pancreatic neuroendocrine tumour. Virchows Arch 426: 523, 1995.

24) Maki M, Kaneko Y, Ohta Y, Nakamura T, Machinami R, Kurokawa K. Somatostatinoma of the pancreas associated with von Hippel-Lindau disease. Intern Med 34: 661, 1995.

25) Reber HA. Rare islet cell tumors of the pancreas. in: Surgical Diseases of the Pancreas, Howard JM, Jordan GL Jr, Reber HA, Eds. Lea and Febiger, Philadelphia, 1987, p. 865.

26) O'Dorisio TM, Vinik AI. Pancreatic polypeptide- and mixed peptideproducing tumors of the gastrointestinal tract. in: Hormone-producing Tumors of the Gastrointestinal Tract, Cohen S, Soloway RD, Eds. Churchill Livingstone Inc., New York, 1985, p. 117.

27) Tomita T, Friesen SR, Kimmel JR, Doull V, Pollock HG. Pancreatic polypeptide-secreting islet-cell tumors: a study of three cases. Am J Pathol 113: 134, 1983.

28) Nobin A, Berg M, Ericsson M, Ingemansson S, Olsson E, Sundler F. Pancreatic polypeptide-producing tumors: report on two cases. Cancer 53: 2688, 1984.

29) Strodel WE, Vinik AI, Lloyd RV, et al. Pancreatic polypeptide-producing tumors: silent lesions of the pancreas? Arch Surg 119: 508, 1984.

30) Neumann HPH, Berger DP, Sigmund G, et al. Pheochromocytomas, multiple endocrine neoplasia type 2, and von Hippel-Lindau disease. $\mathrm{N}$ Engl J Med 329: 1531, 1993. 